Int. J. Sports Medicine 2 (1981) 261-262

(C) Georg Thieme Verlag Stuttgart - New York

\title{
Editorial remark
}

Due to a technical error, the author's substantial revision was not included in the version published in Vol. 2, No. 2. Therefore, the publisher feels obliged to print the following errata.

\section{Errata of: \\ Maximal Aerobic Power in 13- and 14-Year-Old Teenagers in Relation to Biological Age}

\section{H.C.G. Kemper and R. Verschuur}

Int J Sports Med 2: 97-100, 1981

\section{p 98 right column:}

replace lines $14-16$ with:

Differences between chronological age groups and sexes were tested with Student's $t$ test. Differences between biologic age groups were tested with linear regression analyses. Significant differences were tested on a $1 \%$ level of probability $(P<0.01)$.

pp 99 and 100:

replace whole discussion (without Table 5) with:

\section{Discussion}

Godfrey (1974) stated that $\mathrm{VO}_{2}$ max rises with age from 6 to 15 years and that at any age girls have a lower $\mathrm{VO}_{2} \max$ than boys. In our teenagers (see Tables 3 and 4), the 14-year-old boys indeed have higher absolute values in $\mathrm{VO}_{2} \max$ than the 13-year-olds, but in relation to body dimensions the differences in boys disappear. The same holds true for the girls. The higher absolute values of the 14-yearolds are apparently due to growth in body dimensions. At both ages, boys in general have higher absolute and relative $\mathrm{VO}_{2}$ max values than girls.

The $\mathrm{VO}_{2}$ max per $\mathrm{kg}$ body mass in our boys had a mean value of $59 \mathrm{ml} \cdot \mathrm{min}^{-1} \cdot \mathrm{kg}^{-1}$ and in our girls of $51 \mathrm{ml} \cdot \mathrm{min}^{-1} \cdot \mathrm{kg}^{-1}$. These mean values compared with data from teenagers of the same age and sex reported in the literature reveal that our $\mathrm{VO}_{2} \max$ values are quite high. In boys, values vary from 51 to $63 \mathrm{ml} \cdot \mathrm{min}^{-1} \cdot \mathrm{kg}^{-1}$ (Ikai et al., 1972; Hermansen, 1973; Seliger et al., 1976) and in girls from 38 to $52 \mathrm{ml} \cdot \mathrm{min}^{-1} \cdot \mathrm{kg}^{-1}$ (Ikai et al., 1972; Hermansen, 1973; Seliger et al., 1976). Mirwald reported $59 \mathrm{ml} \cdot \mathrm{min}^{-1} \cdot \mathrm{kg}^{-1}$ in the 13- and 14-year-old boys of the Saskatchewan child growth and development study (Mirwald, 1980). However, it must be taken into consideration that comparisons are difficult because different methods of determining $\mathrm{VO}_{2} \max$ are used.

The only available data in The Netherlands are from boys with mean values of $56 \mathrm{ml} \cdot \mathrm{min}^{-1} \cdot \mathrm{kg}^{-1}$ in 1968 (Bink et al., 1968) and $49 \mathrm{ml} \cdot \mathrm{min}^{-1} \cdot \mathrm{kg}^{-1}$ from a current longitudinal study of Binkhorst, De Jong and Vissers (personal communication).
Comparison of our $\mathrm{VO}_{2} \max$ data with those of teenagers from the early studies of Robinson (1938) and Astrand (1952) suggest that a least in our country the fall in endurance fitness is not yet clear at this age. This may be due to the fact that at that age $83 \%$ of the pupils use their bicycles as means of conveyance to and from school.

There are several (longitudinal) studies with teenagers in which also the biologic age is determined (Beunen et al., 1978; Clarke, 1971; Hebbelinck et al., 1980; Prahl-Andersen et al., 1979; Tanner, 1962) and also in which $\mathrm{VO}_{2} \max$ is measured (Mirwald, 1980; Sprynarová, 1974). However, so far there are no publications in which both parameters are measured in the same subjects at comparable ages. Therefore, no comparisons of $\mathrm{VO}_{2}$ max at different biologic ages could be made with the literature. From the results of Table 4, it can be seen that no significant regression could be found across biologic age with $\mathrm{VO}_{2}$ max when expressed in relation to the height squared or the weight to the twothirds power. In other words, biologically older children have $\dot{\mathrm{VO}}_{2}$ max values that are higher than the younger ones, but those higher values are proportional to their body height and body mass.

To determine whether the described changes in $\mathrm{VO}_{2} \max$ (the increase in absolute $\mathrm{VO}_{2} \max$ and the decrease in the $\mathrm{VO}_{2}$ max per $\mathrm{kg}$ body mass) with increasing biologic age is caused by biologic age itself, or by other variables as well, we also analyzed the data of boys and girls with three multiple regression analyses (Table 5) controlling the effect of height, mass, and chronologic age, respectively.

These analyses revealed that almost all the variation in $\mathrm{VO}_{2}$ max was due to the increase in height or mass and that biologic age per se explained only a very small or even an insignificant part of the total variance (see $r^{2}$ changes in Table 5).

However, when changes in $\mathrm{VO}_{2}$ max were analyzed across biologic age, controlled for chronologic age, the reverse was true: most of the explained variation was due to variation in biologic age (see $r^{2}$ changes in Table 5). In other words, in a group of boys and girls of this age, biologic age, or even simpler, body height and mass are the best ways to express $\mathrm{VO}_{2}$ max. 
The finding that biologically older teenagers have lower $\mathrm{VO}_{2} \max$ per $\mathrm{kg}$ body mass is in accordance with the literature, in which is demonstrated that $\mathrm{VO}_{2} \max$ is proportional to body mass to the two-thirds power ( $\AA$ strand et al., 1977).

A decrease in $\mathrm{VO}_{2}$ max per $\mathrm{kg}$ body weight at higher biologic age does not necessarily lead to lower endurance performance. Endurance performances are not only determined by $\dot{\mathrm{VO}}_{2}$ max: a lower $\mathrm{VO}_{2}$ max can be compensated for by a higher mechanical efficiency in the older ones due to higher step length and lower step rate at the same running speed as suggested by Åstrand et al. (1977) or as recently found by Davies (1980) due to the fact that at a certain speed children with a higher body mass have frequencies of leg movement that match better to the force necessary to produce the most economic conversion. Moreover, it is shown that maximal aerobic power more than anything else is related to muscle fiber type and biochemical aspects of substrate utilization and metabolic profile enzyme concentrations.

In conclusion, it can be stated that:

1. In 13- and 14-year-old teenagers, $\mathrm{VO}_{2}$ max increases with chronologic age, but in relation to body dimensions the differences in boys and girls disappear.

2. $\mathrm{VO}_{2} \max$ increases with increasing biologic age proportional to height and mass.

3. Biologic age per se adds hardly anything to the explanation of the development of maximal aerobic power of 13- and 14-year-old teenagers in comparison to height or mass.

\section{References (discussion)}

1 Åstrand P-O., Rodahl K.: Textbook of Work Physiology Physiological Bases of Exercise. New York, McGraw-Hill, 1977.

2 Astrand P-O.: Experimental Studies of Physical Working Capacity in Relation to Sex and Age. Copenhagen, Munksgaard, 1952.

3 Beunen G., Ostyn M., Renson R., Simons J., van Gerven D.: Motor performance as related to age and maturation, in Shephard R.J., Lavallée H. (eds): Physical Fitness Assessment, Principles, Practice and Application. Springfield, Thomas, 1978, pp 229-232.

4 Bink B., Wafelbakker F.: Physical working capacity at maximum levels of work of boys 12-18 years of age. Intern Rep NIPG (TNO) 1968.

5 Clarke H.H.: Physical and Motor Tests in the Medford Boy's Growth Study. Englewood Cliffs, Prenctice-Hall, 1971.

6 Davies C.T.M.: Metabolic cost of exercise and physical performance in children with some observations on external loading. Eur J Appl Physiol 45: 95-102, 1980.

7 Godfrey S.: Exercise Testing in Children, Applications in Health and Disease. London, Saunders, 1974.

8 Hebbelinck M., Blommaert M., Borms J., Duquet W., Vajda A., Van der Meer J.: A multidisciplinary longitudinal growth study introduction of the project "LLEGS", in Ostyn M., Beunen G., Simons J. (eds): Kinanthropometry II. Baltimore, University Park Press, 1980, pp 317-325.

9 Hermansen L.: Oxygen transport during exercise in human subjects. Acta Phys Scand (suppl) 339: 1973.

10 Ikai M., Kitagawa K.: Maximum oxygen uptake of Japanese related to sex and ages. Med Sci Sports (4) 3: 127-131, 1972.

11 Mirwald R.L.: Saskatchewan growth and development study, in Ostyn M., Beunen G., Simons J. (eds): Kinanthropometry II. Baltimore, University Park Press, 1980, pp 289-305

12 Prahl-Andersen B., Kowalski C.J., Heydendael P. (eds): $A$ Mixed Longitudinal Interdisciplinary Study of Growth and Development. Academic Press, 1979.

13 Robinson S.: Experimental studies of physical fitness in relation to age. Arbeitsphysiologie 10: 252-323, 1938.

14 Seliger V., Bartunek (eds): Mean values of various indices of physical fitness in the investigation of Czechoslovak population age 12-55 years. Praha, SCTV, 1976.

15 Sprynarovd S.: Longitudinal study of the influence of different physical activity programs on functional capacity of the boys from 11 to 18 years. Acta Paediatr Belg (suppl) 28: 204--213, 1974.

16 Tanner J.M.: Growth at adolescence. Oxford, Blackwell, 1962. 